\title{
МОДЕЛЮВАННЯ ПОГЛИНАННЯ МІДІ СІЛЬСЬКОГОСПОДАРСЬКИМИ РОСЛИНАМИ В СУЧАСНИХ УМОВАХ ВИРОЩУВАННЯ
}

\author{
В. Ільіна, В. Ніколішін \\ Одеський державний екологічний університет
}

Моделювання $\epsilon$ одним із основних методів дослідження $y$ сучасній екологічній науціi. В рамках роботи, за допомогою математичної моделі, яка дозволяє урахувати рослинні, грунтові, кліматичні та агротехнічні характеристики, виконано моделювання поглинання одного з найбільш токсичних важких металів, до якого відноситься мідь, рослинами иукрового буряку в умовах Херсонської області. Розрахунки проводилися за осередніними даними багатолітнього періоду спостереження, з урахуванням вмісту міді у орному шарі грунту( чорноземи південні), особливостей поглинання міді рослиною та умов вирощування. При изьму виконано аналіз вмісту міді за останні 23 роки. Відзначено, що за останні 5 років спостерігається значне зменшення вмісту міді у грунтах Херсонської області, мабуть за рахунок зменшення використання мінеральних добрив та хімічних засобів захисту рослин, до складу яких входить велика кількість важких металів ( у тому числі міді). Моделювання поглинання виконано для однієї з найбільш розповсюджених та культивуємих сільськогосподарських рослин, до якої належить иукровий буряк. Це питання є досить актуальним завдяки тому, що продуктом переробки иієї культури є продукти харчування, які можуть вміщувати важки метали і визначати екологічну чистоту продукиіï.

Ключові слова: моделювання, важкі металли, математична модель, поглинання.

Вступ. Важкі метали $\epsilon$ сьогодні одним 3 найбільш поширених антропогенних забруднювачів біосфери. Специфіка вирощування сільськогосподарських культур передбачає застосування мінеральних добрив, засобів захисту рослин від шкідливих організмів, стимуляторів та інгібіторів росту, за допомогою яких можна отримати високі врожаї вирощуваних рослин. У той же час агрохімікати представляють загрозу для навколишнього середовища - певна кількість шкідливих для живих організмів речовин може засвоюватись вирощуваними рослинами $\mathrm{i}$ далі за ланцюгами живлення надходити в організм людини.

Проблема. Математичне моделювання, як сучасний апарат дослідження стану екосистеми та агросистеми, як складової, $\epsilon$ досить науково обгрунтованим. Математичне моделювання дозволяє урахувати усі складові та фактори та розробити прогноз можливих змін. Останнє є найбільш актуальним.

Аналіз останніх досліджень i публікацій. Питанням оцінки стану сільськогосподарських угідь займалась досить велика кількість науковців [1]. 
Особливо важливим є питання забруднення агроекосистем важкими металами. При цьому були ураховані основні грунтоутворюючі характеристики [2].

Мета дослідження. Виконати моделювання поглинання найбільш токсичного важкого метала - міді грунтовим покривом сільськогосподарського призначення ( на прикладі умов Херсонської області), що дозволить зробити оцінку швидкості поглинання цього важкого металом рослинами цукрового буряку.

Результати досліджень. Мідь у грунтах $є$ відносно малорухливим елементом. Характерною рисою розподілу міді в грунтовому профілі $є$ ii акумуляція у верхніх горизонтах. Це явище є результатом дії різних чинників, але перш за все концентрація міді у верхньому шарі грунту відображає іiі біоаккумуляцию, а також сучасний антропогенний вплив [1]. Розподіл $\mathrm{Cu}$ у рослинах дуже мінливий. У корінні Сu пов'язана в основному з клітинними стінками і украй малорухлива. У паростках найбільші концентрації міді виявляються завжди у фазі інтенсивного зростання при оптимальному рівні іiі вступу. $\mathcal{C}$ також тенденція до накопичення $\mathrm{Cu}$ у репродуктивних органах рослин, проте йього прояви дуже різні для різних видів рослин [1].Найбільш важливе практичне вживання приведених вище результатів пов'язане 3 проблемами дефіциту i токсичності міді. Дефіцит $\mathrm{Cu}$ відбивається на фізіологічних процесах, а отже, і на продуктивності рослин. Для різних видів рослин вміст, при якому виявляється дефіцит $\mathrm{Cu}$ сильно розрізняються. Проте відомо, що вміст $\mathrm{Cu}$ нижче 2 мг/л небажаний для більшості з них. Витягання $\mathrm{Cu}$ рослинами дуже мале в порівнянні з її вмістом в грунті. В середньому зернові культури витягують 3 грунту приблизно 20 - 30 г/га. Не дивлячись на загальну толерантність рослинних видів і генотипів до міді, цей елемент все ж розглядається як сильно токсичний. Симптомами отруєння міддю, що найбільш зустрічаються, $\epsilon \mathrm{Cu}$-індукований хлороз і пороки розвитку кореневої системи. Передбачити, при яких концентраціях в грунті виникнуть токсичні ефекти в рослинах надзвичайно складно. Вже задовго до того, як симптоми отруєння i зниження врожайності стануть очевидні, продукти живлення, що отримуються 3 сільськогосподарських культур 3 підвищеним рівнем вмісту $\mathrm{Cu}$, представлятимуть значну небезпеку для здоров'я людей [1]. Накопичення важких металів рослиною розглядається в залежності від утримання рухомих форм важких металів у грунті. Швидкість надходження важких металів у рослину описується формулою [1]:

$$
\frac{\Delta \mathrm{A}_{\mathrm{q}}^{\text {погл(o) }}}{\Delta \mathrm{t}}=\frac{86,4 \alpha_{\mathrm{q}}^{\text {погл }} \overline{\mathrm{A}}_{\mathrm{q}}^{\mathrm{rp}} \mathrm{m}_{\mathrm{r}}^{\mathrm{j}}}{\mathrm{a}_{\mathrm{r}}}
$$

де $\frac{\Delta \mathrm{A}_{\mathrm{q}}^{\text {погл }}}{\Delta \mathrm{t}}-$ швидкість поглинання важких металів корінням рослини, мгм ${ }^{-}$ ${ }^{2}$ доб $^{-1} ; \alpha_{\mathrm{q}}^{\text {погл }}-$ поглинальна здібність кореню, $\mathrm{мc}^{-1} ; \overline{\mathrm{A}}_{\mathrm{q}}^{\mathrm{rp}}-$ концентрація рухомих форм g-го виду важких металів у грунті, мгкг ${ }^{1} ; a_{r}$-радіус кореню., см; q - вид важкого металу[1]. 
Таблиця 1. Параметри для розрахунку рівня забруднення міддю ( для цукрового буряку).

\begin{tabular}{|c|c|c|c|}
\hline $\begin{array}{l}\text { Види важких } \\
\text { металів }\end{array}$ & $\begin{array}{c}\text { Поглинальна здібність } \\
\text { коріння, м/ } \mathrm{c}^{2}\end{array}$ & $\begin{array}{l}\text { Концентрація } \\
\text { у грунті, мг/кг }\end{array}$ & $\begin{array}{l}\text { Радіус } \\
\text { кореня }\end{array}$ \\
\hline Мідь $\mathrm{Cu}$ & 0,000028 & 0,74 & 0,0105 \\
\hline
\end{tabular}

При санітарно-гігієнічному нормуванні враховуються показники шкідливості: транслокаційний $\left(\kappa_{1}\right)$ - лімітуючий перехід нормуємої забруднюючої речовини в рослині; міграційний водний $\left(\mathrm{K}_{2}\right)$ - лімітуючий перехід нормуємої забруднюючої речовини в водне середовище; загальносанітарний $\left(\kappa_{3}\right)$ - оцінюючий властивість грунтів до самоочищення $\mathrm{i}$ грунтовий мікробіоценоз (таблиця 2).

Таблиця 2. ГДК міді в грунтах і допустимий вміст по показнику шкідливості.

\begin{tabular}{|c|c|c|c|c|c|}
\hline \multirow{2}{*}{ Елемент } & \multirow{2}{*}{ Клас } & ГДК, мг/кг грунту з & \multicolumn{3}{|c|}{ Показник шкідливості } \\
\cline { 4 - 6 } & небезпеки & урахуванням фону & $\mathrm{K}_{1}$ & $\mathrm{~K}_{2}$ & $\mathrm{~K}_{3}$ \\
\hline $\mathrm{Cu}$ & 2 & 3,0 & 3,5 & 72,0 & 3,0 \\
\hline
\end{tabular}

В районах сільськогосподарської діяльності забруднення грунтів і інших компонентів геологічного середовища пов'язано, насамперед, 3 внесенням добрив та використанням хімічних засобів захисту рослин (таблиця 3 ).

Таблиця 3. Сільськогосподарські джерела забруднення грунтів важкими металами, стосовно Херсонської області.

\begin{tabular}{|c|c|c|c|c|c|}
\hline \multirow{2}{*}{$\begin{array}{c}\text { Елемен } \\
\text { т }\end{array}$} & \multicolumn{4}{|c|}{ Надходження важких металів, мг/кг сухого грунту } \\
\cline { 2 - 6 } & Фосфорні добрива & $\begin{array}{c}\text { Вапнуванн } \\
\text { я }\end{array}$ & $\begin{array}{c}\text { Азотні } \\
\text { добрива }\end{array}$ & $\begin{array}{c}\text { Органічні } \\
\text { добрива }\end{array}$ & $\begin{array}{c}\text { Пестицид } \\
\text { и }\end{array}$ \\
\hline $\mathrm{Cu}$ & $10-200$ & $10-100$ & $1-15$ & $2-60$ & $15-50$ \\
\hline
\end{tabular}

Херсонська область відноситься до найбільш проблемних, з точки зору вирощування сільськогосподарських рослин, у зв язку із недостатнім рівнем родючості та посушливими умовами вирощування. На рисунку 1 представлена динаміка забруднення грунтів Херсонської області міддю (рухлива форма) . Аналізуючи графік видно, що розподіл динаміки забруднення грунтів міддю $є$ нерівномірним. Спостерігається 3 максимуми у 1992, 1995 і 2000 роках зі значеннями 1,367 мг/кг, 1,308 мг/кг і 1,324 мг/кг відповідно ( при цьому перевищень ГДК не спостерігалося). Мінімальні значення спостерігалися на початку досліджуваного періоду і складали біля 0,2 мг/кг. За останні роки вміст міді у грунтах сільськогосподарського призначення в середньому дорівнювався $0,5 \mathrm{мг} / \mathrm{к \Gamma} \mathrm{.}$

За допомогою наведеної вище математичної моделі було розрахована швидкість поглинання рухомих форм міді корінням цукрового буряку в середньому за період з 1992 по 2013 роки в умовах Херсонської області (рисунок 2). 


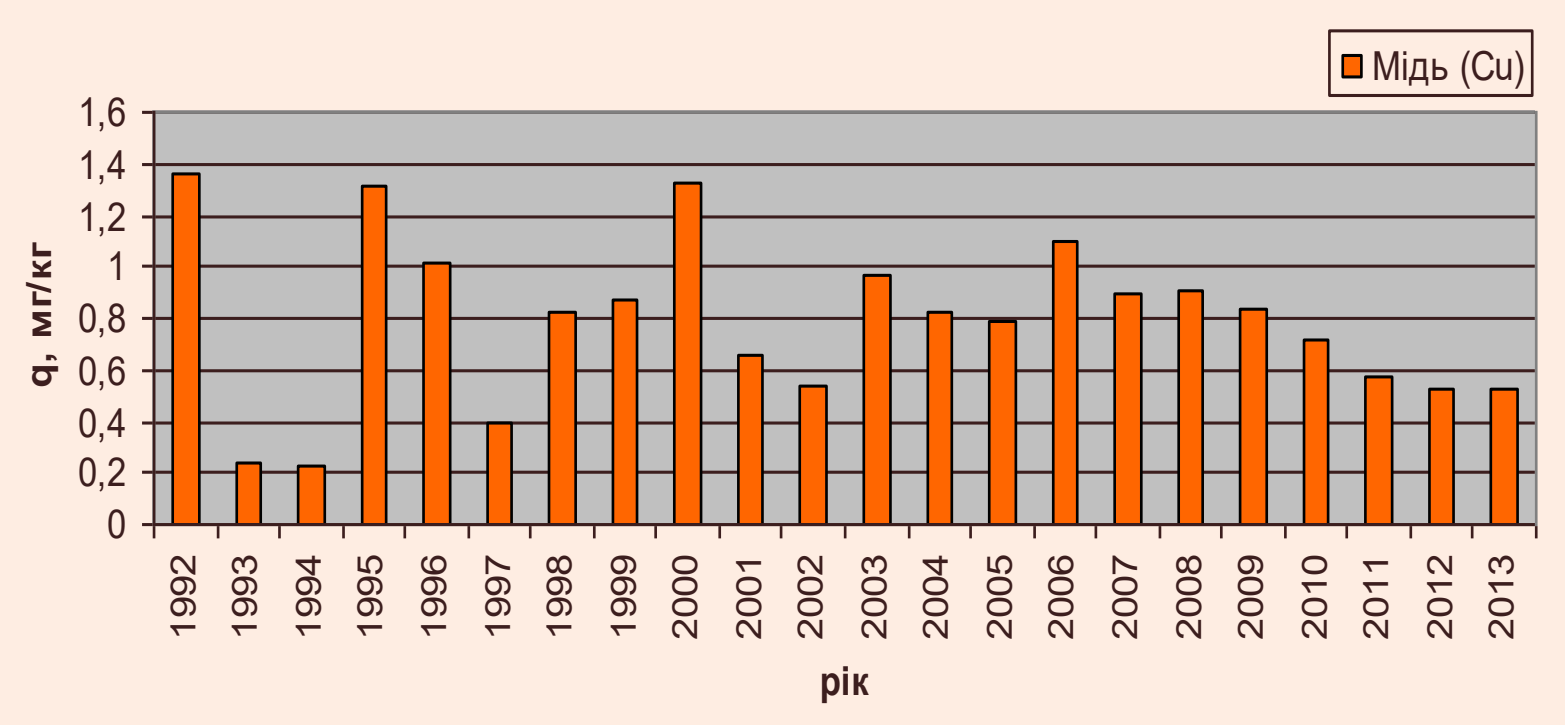

Рис.1. Динаміка забруднення грунтів Херсонської області міддю (рухлива форма)



Рис.2. Швидкість поглинання рухомих форм Сu цукровим буряком

Висновки. Аналізуючи графік, видно, що швидкість важкого металу - міді знаходиться в тісній залежності від концентрації його у грунті а також від умов вирощування. Розрахунки проводилися для чорноземів південних. Для інших типів грунтів моделювання поглинання міді буде виконано у подальшому. За допомогою моделі буде оцінено швидкість поглинання для інших сільськогосподарських рослин. 


\section{ЛІТЕРАТУРА}

1. Грабак Н.Х., Топіха I.Н., Давиденко В.М., Шевель І.В. Основи ведення сільського господарства та охорона земель: навчальний посібник, 2-е видання. Київ: ВД «Професіонал», 2006 - 496 с.

2. Жовинский Э.Я., Кураева И.В. Геохимия тяжелых металлов в почвах Украины. - Київ: Наукова думка, 2002. - 213 с.

3. Кабата-Пендиас А. Микроэлементы в почвах и растениях / А. КабатаПендиас, Х. Пендиас; пер. с. англ. - Москва: Мир, 1989. - 439 с.

\section{МОДЕЛИРОВАНИЕ ПОГЛОЩЕНИЯ МЕДИ СЕЛЬСКОХОЗЯЙСТВЕННЫМИ РАСТЕНИЯМИ В СОВРЕМЕННЫХ УСЛОВИЯХ ВЫРАЩИВАНИЯ}

Ильина В., Николишин В.

Моделирование является одним из основных методов исследования в современной экологической науки. $B$ рамках работы, $c$ помощью математической модели, которая позволяет учесть растительные, почвенные, климатические и агротехнические характеристики, выполнено моделирование поглощения одного из самых токсичных тяжелых металлов, $\kappa$ которому относится медь, растениями сахарной свекль в условиях Херсонской области. Расчеты проводились по осредненным данным многолетнего периода наблюдения, с учетом содержания меди в пахотном слое почвы (черноземы южные), особенностей поглощения меди растением и условий выращивания. При этом выполнен анализ содержания меди за последние 23 года. Отмечено, что за последние 5 лет наблюдается значительное уменьшение содержания меди в почвах Херсонской области, за счет уменьшения использования минеральных удобрений и химических средств защиты растений, в состав которых входит большое количество тяжелых металлов (в том числе меди). Моделирование поглощения выполнено для одной из самых распространенных и культивируемых сельскохозяйственных культур, к которой принадлежит сахарная свекла. Этот вопрос является весьма актуальным благодаря тому, что продуктом переработки этой культуры являются продукты питания, которые могут содержать тяжелые металль и определять экологическую чистоту продукиии.

Ключевые слова: моделирование, тяжелье металли, математическая модель, поглощение.

\section{MODELING OF MAGNESTRUCTURE BY AGRICULTURAL PLANTS IN MODERN GROWING CONDITIONS}

Ilina V., Nikolishen V.

Modeling is one of the main methods of research in modern environmental science. In the framework of the work, using a mathematical model that allows for the consideration of vegetative, soil, climatic and agronomic characteristics, the simulation of the absorption of one of the most toxic heavy metals, including copper, sugar beet plants in the Kherson region, was performed. The calculations were carried out according to the averaged data of the long-term observation period, 
taking into account the copper content in the arable layer of soil (southern black earths), the characteristics of copper absorption by the plant and the conditions of cultivation. In this case, the analysis of copper content over the past 23 years. It is noted that during the last 5 years there has been a significant decrease in the content of copper in the soils of the Kherson region, apparently due to reduced use of mineral fertilizers and chemical protection products of plants, which includes a large number of heavy metals (including copper). Absorption simulation is performed for one of the most widely spread and cultivated agricultural plants, which includes sugar beet. This question is very relevant due to the fact that the product of processing this crop are foods that can hold heavy metals and determine the ecological purity of products.

Key words: modeling, heavy metals, mathematical model, absorption. 